\title{
EEN OUDE GETUIGENIS OVER DE GENEZING VAN SLANGENBEET EN AARDETEN
}

DooR

\section{LOU LICHTVELD}

Reeds in zijn eerste artikel over "Snettii-koti” heeft dr. H. D. Benjamins gezegd, dat de Surinaamsche geneeswijze van, en de voorbehoedmiddelen tegen slangenbeet Afrikaansch import waren. Ik heb getracht bewijsmateriaal voor deze stelling bijeen te brengen, en het is thans een uitgemaakte zaak. Ook heb ik gewezen op het voorkomen van analoge gebruiken onder Noord-Amerikaansche negers, doch eerst sedert kort is mij een waardevolle getuigenis ter kennis gekomen van het bestaan en de uitwerking van „,snetji-koti”, en wel onder de negers van het eiland Martinique, reeds op het einde van de 17 de eeuw.

Dat behoeft niemand te verwonderen. De negers die op de Antillen werden aangevoerd, waren geen andere dan die men in Suriname ontscheepte. Zij behoorden tot dezelfde Westafrikaansche volksstammen, en hadden dezelfde gebruiken. In zooverre leert ons het relaas dat hier ter sprake wordt gebracht niets nieuws. Maar wel is het waardevol, omdat het afkomstig is van een der schranderste reisbeschrijvers, een missionaris die in een roemrijk tijdperk van West-Indië al de Antillen gedurende twaalf jaar heeft afgereisd, en daar een nauwkeurige kennis heeft opgedaan, zoowel van de aanwezige Caraïben als van de verschillende soorten negerslaven. Hij kon met beide bevolkingsgroepen in hun eigen talen verkeeren, en daar hij een man was van zeer veelzijdige kennis, munten al zijn mededeelingen over de Antillen uit door hun rijkdom aan bijzonderheden, hun groote exactheid en betrouwbaarheid. 
Het is niemand minder dan de beroemde Père Labat, die iedereen van naam kent, maar wiens beide oorspronkelijke werken, de „Nouveau Voyage aux isles de l'Amérique" (zes deelen, het eerst in 1722 verschenen) en zijn „Voyages en Espagne et en Italie” helaas veel minder gelezen en gekend zijn, dan de reisbeschrijvingen van anderen, die hij met zooveel smaak wist te bewerken.

Toen deze Fransche Dominicaan in 1693 naar Martinique vertrok, bezat hij al de orthodoxie waarvoor zijn orde bekend is. Die orthodoxie heeft hij ook na twaalf jaar missiearbeid en een heel leven van strubbelingen met zijn oversten in Europa niet verloren. Maar wel zien wij hem bij het schrijven van zijn boeken geneigd tot het aannemen van wonderlijke verschijnselen die hij niet door goddelijke inwerking kon verklaren, en die hij dus op rekening van de duivel meende te moeten stellen. Doch niet voor en aleer hij zich geheel had uitgeput in het geven van „natuurlijke” verklaringen.

Nog slechts heel kort bevond hij zich op Martinique, toen men hem kwam halen om de biecht te hooren van een neger, die door een slang gebeten was, en die men dus klaarblijkelijk in levensgevaar dacht. Wat Père Labat daar meemaakte vond hij zoo belangrijk, dat hij er een zeer gedetailleerd verslag van gaf in het 7de hoofdstuk van Boek I van zijn „Voyage aux isles de l'Amérique”.

De neger was gebeten door een slang van zeven voet lengte en de dikte van een mannenbeen. Labat beschrijft nauwkeurig hoe hij de kop van het dier onderzocht, en hij geeft een voorbeeldige uiteenzetting van de stand en werking der giftanden.

„J'en fis arracher un et je remarquai qu'il était creux depuis sa naissance jusqu'aux deux tiers de sa longueur, où il $\mathrm{y}$ avait un petit trou; ces dents sont mobiles et sont accompagnées, à l'endroit où elles sont attachées aux gencives, d'une petite pellicule en manière de vessie remplie de venin".

Hij heeft zich dus wel wis en degelijk overtuigd van het feit dat de neger door een giftige slang gebeten was. Het slachtoffer was er dan ook naar aan toe, al hadden 
zijn kameraden hem reeds „in behandeling” genomen. Men had het dier gedood in de verwachting ,que le serpent étant mort, le venin agirait avec moins de force sur celui qui avait été mordu. J'en demandai la raison, qu'on ne me put dire".

Terecht merkt Labat op, dat zulk een voorstelling van zaken overeenstemt met de sympathische geneeswijze. Maar hij voegt er aan toe: ,je ne sais s'ils connaissent cette vertu".

De neger was in wollen dekens gewikkeld, er werden twee vuren bij hem gestookt, en niettemin klaagde hij te sterven van de kou, van dorst en van slaap. Gewone vergiftingsverschijnselen, volgens de missionaris.

Het gebeten been was sterk afgebonden met een liaan, zoowel boven als beneden de knie. „La jambe et le pied étaient horriblement enflés et le genou, malgré les ligatures, l'était un peu". De zieke sprak zijn biecht, maar om hem wakker te doen blijven moest de pater zijn hand vasthouden en voortdurend bewegen.

Toen liet hij de neger roepen die de zieke verzorgd had, en vroeg hem naar zijn meening. Hij antwoordde dat er gevaar was, en dat hij niets zeggen kon vóor het een etmaal verder was.

Gevraagd naar zijn geneeswijze en medicijnen, weigerde de neger deze mede te deelen, omdat dit geheim zijn broodwinning beteekende. Maar wanneer de priester zelf gebeten was, wilde hij hem gaarne behandelen!

Toch wist père Labat, die voor geen kleintje vervaard was, de neger aan 't spreken te krijgen. In de eerste plaats, zei deze, moest het gebeten lidmaat 7 à 8 vingers boven de wonde afgebonden worden, en in de nabijheid van een gewricht ook dààrboven. Onverwijld moest dan de patient naar huis, zonder te drinken, tenzij z'n eigen urine, wat in zulk een geval een krachtig tegengif zou zijn!

Voorts zei de neger, dat hij er goed op lette of er één dan wel twee giftanden in het vleesch gedrongen waren. Naar gelang daarvan zette men één of twee koppen op, na insnijdingen over de beet gemaakt te hebben. Door krachtig de omgeving van de beet te drukken, trachtte 
men het uittreden van bloed en venijn te bevorderen. Zoo noodig zet men twee- tot driemaal nieuwe koppen.

Tegelijk met deze uitwendige behandeling past men ook een inwendige toe. Vóór alles krijgt de patient een goed glas brandewijn of dram (,eau-de-vie de cannes”), waarin „une once de thériaque ou d'orviétan”. Dit „driakel of kwakzalversmiddel" wordt niet nader bekend gemaakt, en maakt dus deel uit van 's negers geheim.

Intusschen stampt men in een vijzel een bolletje knoflook, een handvol ",liane brûlante”, wat waterpostelein, „de la malnommée et deux ou trois autres sortes d'herbes ou racines", waarvan men de naam niet wilde zeggen. Dit vermengt men met poeder van de slangenkop en wat brandewijn. De patient heeft dit mengsel te drinken nadat de koppen gezet zijn. Het bezinksel wordt bij wijze van pleister op de wonde gelegd, en men heeft nu maar te zorgen dat de zieke zoo warm mogelijk blijft, de eerste 24 uren niet slaapt en niets anders drinkt dan een afkooksel van bovengenoemde kruiden, met water, citroensap en brandewijn vermengd.

De pleister wordt na 12 uren verwijderd, en door een soortgelijke vervangen, zoo lang als het noodig blijkt. In drie of vier dagen is alles genezen, tenzij de beet een belangrijk bloedvat heeft getroffen, in welk geval alle pogingen vruchteloos zijn en de patient in 12 of 15 uren sterft.

$\mathrm{Er}$ is nog een andere manier, schrijft père Labat, namelijk die van de wond uit te zuigen; maar het is een manier die voor de dokter even gevaarlijk is als voor de patient.

$\mathrm{Na}$ al deze wetenschap te hebben opgedaan, vertrok de missionaris. Reeds de volgende dag ontving hij een bericht dat de neger buiten gevaar was. De behandeling had dus geholpen.

Dit relaas is in verschillende opzichten leerzaam.

Ten eerste bewijst het, dat de toenmalige negers van Martinique een geneeswijze kenden van vergiftigde slangenbeten, die ontdaan van alle ,geheime" elementen, van alle magie en van alle sympathische betrekkingen tot 
de slang, meer dan genoeg „natuurlijke” elementen bevatte om een genezing te kunnen bewerkstelligen.

Ten tweede, dat bij de behandeling de verbrande slangenkop weliswaar slechts een van de vele onderdeelen was waaruit de remedie bestond, maar dat deze zoowel in- als uitwendig werd toegediend, gelijk dat ook in Suriname en elders het geval is.

Ten derde, dat de negers van Martinique hun middel geenszins als onfeilbaar beschouwden, maar vooral groote waarde hechtten aan snelle en geheele verwijdering van het venijn, en door afbinden trachtten verdere verspreiding ervan in het lichaam te voorkomen.

De neger die père Labat inlichtte in het jaar 1693, had klaarblijkelijk een juist inzicht in het proces en de therapie van de slangenbeet. Van een prophylaxe wordt nergens gesproken.

Misschien is het niet overmoedig hieraan een kleine hypothese vast te knoopen. Ik geloof aan het bestaan van een jungle-wijsheid; een uit ervaring opgebouwde kunde om aan de verschillende gevaren van het oerwoud het hoofd te bieden. Een deel van deze kennis is een zeer reëele, en onaantastbare geneeskunde. Maar de primitieve mensch bezat haar nooit geïsoleerd; zij werd altijd vermengd met eenige magie. Et pour cause! Het is zelfs bij ons dikwijls nog niet anders.

$\mathrm{Nu}$ doet zich het verschijnsel voor, dat soms de kunde geheel of gedeeltelijk verloren raakt en de magie overblijft of overschat wordt, eventueel de kunde overwoekert. Dat schijnt in Suriname het geval. Terwijl men de omgekeerde gang van zaken kon waarnemen op het Martinique van meer dan twee eeuwen geleden.

Heeft de negerdokter het veiliger geacht om zich tegenover de inquisitorische père Labat over die magie niet verder uit te laten? De verstandige zendeling heeft ten aanzien van het werk der ,nègres sorciers” een uitspraak gedaan, die liberaal en voorzichtig genoeg is om alle partijen ter overweging te dienen: "Je sais qu'on exagère souvent dans ce qu'on en dit, mais je crois qu'il faut con- 
venir que tout ce qu'on en dit n'est pas entièrement faux, quoiqu'il ne soit peut-être pas entièrement vrai".

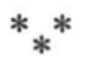

In hoofdstuk II van het tweede boek van zijn „Voyage aux isles de l'Amerique" spreekt père Labat met zijn gebruikelijke uitvoerigheid over het aardeten door negers. En daar de Encyclopaedie van Ned. W. I. i.v. „Aardeten” zijn getuigenis niet vermeldt, wijs ik er hier terloops op. Wat deze schrijver mededeelt is immers veel ouder dan het weinige dat door Hartsinck ervan gezegd wordt, en vooral veel uitvoeriger.

Père Labat maakt een duidelijk onderscheid tusschen verschillende vormen en oorzaken van aardeten. Hij bezat zelf een slaafje van 12 à 13 jaar, afkomstig uit Elmina, dat ondanks alle moeite om het hem te beletten, aarde at. Hij was niet te genezen ,parcequ'on ne pouvait pas en ôter la cause, qui était une mélancholie noire qui le portait à cet excès". Eerst toen het te laat was leerde de meester van het knaapje de oorzaak van die melancholie, - scheiding van zijn broertje en heimwee naar de ouders - , kennen. Hij had het ventje gedoopt, en op zijn verwijt dat het zelfmoord beging, begon het te schreien. „Il disait qu'il m'aimait, mais qu'il voulait retourner chez son père"'. Hij stierf en werd weldra gevolgd door zijn broeder.

Volgens de schrijver hebben vooral de negers van de kust van Elmina deze gewoonte gehad (volgens Hartsinck de Foin-negers, volgens Hostmann de Doema-koekoe's), en wel uit wraakgevoel tegen hun meesters en omdat zij geloofden na hun dood weer naar hun geboorteland terug te keeren. Niet alleen aarde eten de negers in die staat van zwaarmoedigheid, maar ook asch, kalk en dergelijke dingen meer. "Je dirai dans un autre endroit mes conjectures sur cela", zegt Labat, die werkelijk in hoofdstuk 9 van boek VI zegt, dat de negers zich zelden aan dergelijke wanhoopsdaden te buiten gaan, wanneer ze eenmaal goed en wel gedoopt zijn. Het is de duivel die ze daartoe aanspoort.... 
„Sans entrer ici dans la discussion, si ce sont de simples effets de leur imagination blessée ou une obsession réelle et véritable, car le monde est à présent rempli d'esprits forts, qui se piquent de ne croire que ce qu'ils ont vu, nous nous servons d'un remède qui les guérit ou les délivre infailliblement. Ce remède est le baptème".

Op wat hij beschouwt als een zielsziekte past hij dus een ",psychische” behandeling toe. De religie had voor père Labat ook haar practische waarde!

Overigens zegt hij, op de eerst aangehaalde plaats, dat het verschijnsel toch ook zeer algemeen is onder de gedoopte creolen, en speciaal onder de trouwlustige meisjes. „Dans cet état elles mangent mille ordures. J'en ai connu qui auraient mangé plus de papier et de cire d'Espagne qu'on n'en aurait employé dans le bureau d'un secrétaire d'Etat; d'autres mangent des pipes, des charbons, de la toile et surtout certains petits cailloux blancs qu'on trouve dans les rivières; elles les font cuire dans le feu comme les roches à chaux et les mangent comme la meilleure chose du monde...."

Niets kan ze ervan weerhouden, de meisjes worden geel, lijkkleurig, krijgen zwarte kringen om de oogen, zijn mager, kribbig, indolent, ondragelijk voor anderen en zichzelf. Ze verliezen alle eetlust in behoorlijk voedsel en krijgen een ongeneeslijke waterzucht.

In hedendaagsche taal zou men spreken van een vorm van hysterie. En Labat dacht vast wel aan iets dergelijks, want hij besluit heel oolijk: „Le meilleur remède qu'on y puisse apporter dès qu'on s'en aperçoit, est de les marier".

Wat hij vertelt, stemt merkwaardig goed overeen met het door dr. Richard Lasch over geophagie meegedeelde en in de Encyclopaedie van Ned. W. I. geciteerde. Van anchylostomiasis wist de goede père Labat niets af, maar 't was een psycholoog, en een anthropoloog die zijn tijd ver vooruit liep! 